\title{
Estimating millennial-scale rates of dust incorporation into eroding hillslope regolith using cosmogenic nuclides and immobile weathering tracers
}

\author{
Ken L. Ferrier, ${ }^{1}$ James W. Kirchner, ${ }^{2,3,4}$ and Robert C. Finkel ${ }^{4,5}$ \\ Received 11 February 2011; revised 1 June 2011; accepted 13 June 2011; published 15 September 2011.
}

[1] Dust fluxes are of wide interest because of the effects of dust on climate, oceanic primary productivity, terrestrial biogeochemical cycles, and regolith composition. Estimating longterm dust deposition rates, however, can be difficult, especially in steep, eroding terrain. Here we present a geochemical mass balance method for estimating long-term average rates of dust incorporation into regolith on steadily eroding hillslopes. This method requires measurements of the local regolith production rate and the concentrations of two immobile elements in the regolith, its parent rock, and dust. Dust incorporation rates inferred with this method are averaged over the long timescale of regolith residence on the hillslope (typically $10^{3}-10^{5}$ years), and thus may serve as long-term averages against which modern-day dust fluxes may be compared. We apply this model to 17 field sites in the South Fork of the Salmon River in the Idaho Batholith, where rock and regolith compositions imply that mafic-rich material has been added to the otherwise granitic regolith. We suggest that the most likely source of this mafic material is dust sourced from the same glacial outburst flood sediments that generated the Palouse loess on the Columbia Plateau, and we use the published composition of these sediments to infer dust incorporation rates of $3-13 \mathrm{t} \mathrm{km}^{-2} \mathrm{yr}^{-1}$ at these sites, comparable to modern-day dust fluxes elsewhere in the western United States.

Citation: Ferrier, K. L., J. W. Kirchner, and R. C. Finkel (2011), Estimating millennial-scale rates of dust incorporation into eroding hillslope regolith using cosmogenic nuclides and immobile weathering tracers, J. Geophys. Res., 116, F03022, doi:10.1029/2011JF001991.

\section{Introduction}

[2] As the orange-red skies in Sydney, Australia colorfully demonstrated in September 2009, the atmosphere is capable of transporting a great deal of mineral mass. It exercises this ability regularly. Globally, the continents send about $1700 \mathrm{Tg}$ of dust into the atmosphere every year, of which about $450 \mathrm{Tg}$ falls to the oceans and $1250 \mathrm{Tg}$ returns to land [Jickells et al., 2005]. This dust flux has widespread consequences. It influences climate by affecting radiative transfer [e.g., Harrison et al., 2001], it promotes marine primary productivity by fertilizing Fe-limited regions of the oceans [e.g., Fung et al., 2000], and, where it returns to land, it affects

\footnotetext{
${ }^{1}$ Department of Earth, Atmospheric, and Planetary Sciences, Massachusetts Institute of Technology, Cambridge, Massachusetts, USA.

${ }^{2}$ Swiss Federal Institute for Forest, Snow, and Landscape Research (WSL), Birmensdorf, Switzerland.

${ }^{3}$ Department of Environmental Sciences, Swiss Federal Institute of Technology (ETH), Zurich, Switzerland.

${ }^{4}$ Department of Earth and Planetary Science, University of California, Berkeley, California, USA.

${ }^{5}$ Center for Accelerator Mass Spectrometry, Lawrence Livermore National Laboratory, Livermore, California, USA.

Copyright 2011 by the American Geophysical Union. 0148-0227/11/2011JF001991
}

regolith composition [e.g., Rex et al., 1969]. If the $1250 \mathrm{Tg}$ of land-bound dust were distributed evenly over all terrestrial landmasses, it would produce a dust deposition rate of roughly $8 \mathrm{t} \mathrm{km}^{-2} \mathrm{yr}^{-1}$. Relative to a present-day globally averaged denudation rate of roughly $140 \mathrm{t} \mathrm{km}^{-2} \mathrm{yr}^{-1}$ [Wilkinson and McElroy, 2007], which, in steady state, must roughly equal the rate at which fresh minerals are supplied to the regolith from the underlying rock, dust deposition should be a secondary but non-trivial source of minerals and nutrients to Earth's regoliths.

[3] This is confirmed by a number of studies that have found that dust is an important contributor to regolith composition, both in arid to semi-arid regoliths of the western United States [e.g., Marchand, 1970; Litaor, 1987; Harden, 1988; Chadwick and Davis, 1990; Reheis, 1990; Reheis and Kihl, 1995; Reheis et al., 1995, 2009; Dahms, 1993; Reynolds et al., 2006; Goldstein et al., 2008] and elsewhere around the globe [e.g., Rex et al., 1969; Muhs et al., 1990; Brimhall et al., 1988; Chartres et al., 1988; Chadwick et al., 1999; Kurtz et al., 2001; Stiles et al., 2003; Porder et al., 2007; Pett-Ridge et al., 2009]. As many of these studies have noted, incorporation of dust into regolith has consequences for geomorphic and geochemical studies that use the rock-to-regolith enrichment of chemically immobile elements as a tool for inferring rates and processes of regolith 


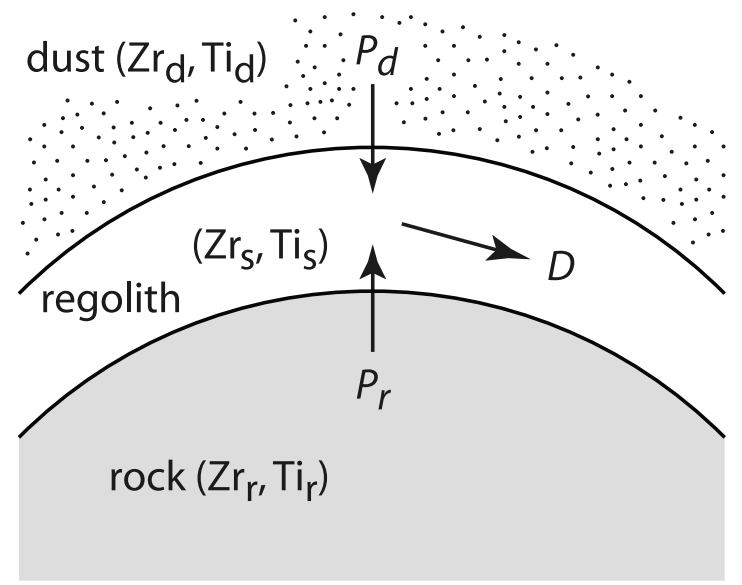

Figure 1. Schematic of a steadily eroding regolith. In steady state the regolith denudation rate $D$ is balanced by the sum of the regolith production rate $P_{r}$ and the rate of dust incorporation into the regolith $P_{d}$, and the concentrations of chemically immobile elements in the regolith $\mathrm{Zr}_{s}$ and $\mathrm{Ti}_{s}$ remain constant over time.

formation, chemical weathering, and physical erosion [e.g., Brimhall and Dietrich, 1987; Brimhall et al., 1992; White et al., 1998; Riebe et al., 2001, 2003, 2004a, 2004b; Green et al., 2006; Yoo et al., 2007, 2009; Burke et al., 2007, 2009; Dixon et al., 2009a, 2009b]. Because the elements typically considered to be immobile are present in small quantities in most regoliths, their concentrations in regolith can be altered by small additions of atmospheric dust, especially if the dust is rich in these elements. Quantifying the influence of dust on regolith composition (and hence on chemical and physical erosion rates inferred from regolith composition) thus requires estimates of dust composition and rates of dust incorporation into regolith.

[4] It can, however, be difficult to estimate dust fluxes, especially over the long timescales relevant to regolith formation and erosion. Here we present a method for estimating long-term rates of dust incorporation into regolith averaged over the regolith residence time, which on most eroding hillslopes is on the order of $10^{3}-10^{5}$ years. This method requires estimates of regolith production rates (which are now routinely inferred from cosmogenic nuclide concentrations in regolith or the underlying rock) and concentrations of two immobile elements in the rock, regolith, and dust (which may be measured by a variety of geochemical techniques). The approach proposed here complements other methods for quantifying long-term dust fluxes, such as measuring loess thickness accumulated over a known time interval [e.g., Busacca et al., 2004], or attributing discrepancies in $\mathrm{Sr}$ isotope fluxes in and out of a catchment to dust deposition [e.g., Pett-Ridge et al., 2009].

\section{A Hillslope Mass Balance Framework for Estimating Rates of Dust Incorporation Into Regolith}

[5] Consider a scenario in which a steady state regolith on a hillslope receives influxes of material from two sources: incorporation of the underlying rock into the regolith at a steady regolith production rate $P_{r}$, and dust incorporation into the regolith at a steady rate $P_{d}$ (Figure 1). In the following derivation we use the term regolith as it is conventionally defined in the geomorphic literature, i.e., as the layer of physically mobile material in the uppermost portion of the weathering profile. This definition is functionally equivalent to the definition of the partially disturbed zone [Yoo and Mudd, 2008] and the definition of soil in some studies [e.g., Heimsath et al., 1997]. It differs from the conventional geochemical definition of regolith, in which regolith comprises both the physically mobile layer and an underlying layer which is physically static but chemically altered relative to the parent rock beneath it [e.g., Brantley et al., 2008]. Similarly, for the sake of simplicity in this derivation we call the parent material underlying the regolith bedrock, although in many field settings the material underlying the regolith has undergone some chemical weathering and may be more accurately termed saprolite, saprock, or weathered rock. Central to the following derivation is the steady state assumption, which requires that the total rate of mass addition to the regolith $\left(P=P_{r}+P_{d}\right)$ be balanced by the regolith denudation rate $D$, which itself is the sum of the physical erosion rate $E$ and the chemical erosion rate $W$. Similarly, for the regolith to be in compositional steady state, the influx of each element $\mathrm{X}$ to the regolith must be balanced by the efflux of $X$ out of the regolith. Here and elsewhere in this paper, we consider $D, E, W$, $P, P_{r}$, and $P_{d}$ to be mass fluxes per unit area of hillslope $\left(\mathrm{M} \mathrm{L}^{-2} \mathrm{~T}^{-1}\right)$. Here we note that although the equations in the following mathematical framework are built on the assumption of a steady state regolith and thus are most accurate when the regolith is in steady state, these equations are in fact relatively insensitive to deviations from exact steady state [Ferrier and Kirchner, 2008]. This is because many of the equations in this framework are based on the mean regolith composition, which itself is relatively insensitive to temporary fluctuations in mass fluxes into and out of the regolith [Ferrier and Kirchner, 2008]. Assuming that downslope gradients in regolith chemistry are negligible (a good approximation at hilltops and ridgelines [Mudd and Furbish, 2006; Yoo et al., 2007]) the steady state mass balance equations for the bulk regolith and for an element $\mathrm{X}$ may be written as follows.

$$
\begin{gathered}
P=P_{r}+P_{d}=D=E+W \\
P_{\mathrm{X}}=P_{r} \mathrm{X}_{r}+P_{d} \mathrm{X}_{d}=D_{\mathrm{X}}=E \mathrm{X}_{s}+W_{\mathrm{X}}
\end{gathered}
$$

Here $P_{r}$ is the regolith production rate $\left(\mathrm{M} \mathrm{L}^{-2} \mathrm{~T}^{-1}\right), P_{d}$ is the dust incorporation rate $\left(\mathrm{M} \mathrm{L}^{-2} \mathrm{~T}^{-1}\right), P$ is the total mass flux into the regolith $\left(\mathrm{M} \mathrm{L}^{-2} \mathrm{~T}^{-1}\right), P_{\mathrm{X}}$ is the total flux of element $\mathrm{X}$ into the regolith $\left(\mathrm{M} \mathrm{L}^{-2} \mathrm{~T}^{-1}\right), D_{\mathrm{X}}$ is the total flux of element $\mathrm{X}$ out of the regolith $\left(\mathrm{M} \mathrm{L}^{-2} \mathrm{~T}^{-1}\right), E$ is the physical erosion rate $\left(\mathrm{M} \mathrm{L}^{-2} \mathrm{~T}^{-1}\right), W_{\mathrm{X}}$ is the chemical erosion rate of $\mathrm{X}\left(\mathrm{M} \mathrm{L}^{-2}\right.$ $\mathrm{T}^{-1}$ ), and $X_{r}, X_{s}$, and $X_{d}$ are the concentrations (M/M) of X in the bedrock, regolith, and dust, respectively. In the case of a chemically immobile element (e.g., $\mathrm{Zr}$ ), $W_{\mathrm{Zr}}=0$ and equation (2) may be solved for the physical erosion rate $E$ (equation (3)). This expression for $E$ may be substituted into equations (1) and (2) to yield expressions for the bulk 


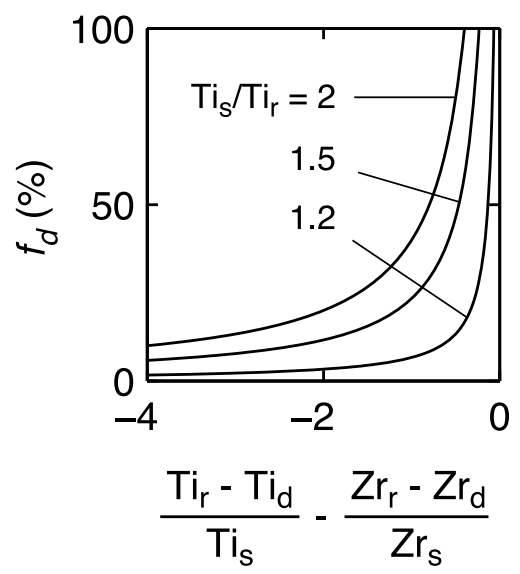

Figure 2. Dust fraction $f_{d}$ predicted by equation (13) versus the denominator in equation (13) for three example model scenarios (contour lines). Values for four parameters were held constant in each of these example scenarios at $\mathrm{Zr}_{\mathrm{r}}=$ $90 \mathrm{ppm}, \mathrm{Zr}_{\mathrm{s}}=100 \mathrm{ppm}, \mathrm{Ti}_{\mathrm{r}}=0.1 \%$, and $\mathrm{Ti}_{\mathrm{d}}=1 \%$, and a range of values for the $x$ axis was generated using a range of values in $Z_{\mathrm{d}}$ and the three values for $\mathrm{Ti}_{\mathrm{s}}$. Predicted values of $f_{d}$ approach infinity as $\left(\mathrm{Ti}_{\mathrm{r}}-\mathrm{Ti}_{\mathrm{d}}\right) / \mathrm{Ti}_{\mathrm{s}}$ approaches $\left(\mathrm{Zr}_{\mathrm{r}}-\mathrm{Zr}_{\mathrm{d}}\right) / \mathrm{Zr}_{\mathrm{s}}$, which limits the applicability of equation (13) to field settings where this is not the case.

chemical erosion rate $W$ and the elemental chemical erosion rate $W_{\mathrm{X}}$.

$$
\begin{gathered}
E=P_{r} \frac{\mathrm{Zr}_{r}}{\mathrm{Zr}_{s}}+P_{d} \frac{\mathrm{Zr}_{d}}{\mathrm{Zr}_{s}} \\
W=P_{r}\left(1-\frac{\mathrm{Zr}_{r}}{\mathrm{Zr}_{s}}\right)+P_{d}\left(1-\frac{\mathrm{Zr}_{d}}{\mathrm{Zr}_{s}}\right) \\
W_{\mathrm{X}}=P_{r}\left(\mathrm{X}_{r}-\mathrm{X}_{s} \frac{\mathrm{Zr}_{r}}{\mathrm{Zr}_{s}}\right)+P_{d}\left(\mathrm{X}_{d}-\mathrm{X}_{s} \frac{\mathrm{Zr}_{d}}{\mathrm{Zr}_{s}}\right)
\end{gathered}
$$

Equations (3)-(5) provide a straightforward framework for estimating steady state chemical and physical erosion rates if the dust flux $P_{d}$ and dust composition are known. However, measuring $P_{d}$ can be difficult, especially over the long timescales of regolith production and erosion which are relevant to this approach. Below we show how to estimate the magnitude of $P_{d}$ by using the regolith production rate $P_{r}$ and the concentrations of two immobile elements in the bedrock, regolith, and dust. We begin by defining a new term, $f_{d}$, as the fraction of the regolith's parent material that is dust.

$$
f_{d}=\frac{P_{d}}{P_{r}+P_{d}}
$$

Under this definition, the dust incorporation rate $P_{d}$ may be rewritten as a function of the regolith production rate $P_{r}$.

$$
P_{d}=\frac{P_{r} f_{d}}{1-f_{d}}
$$

The total supply rate of an element $\mathrm{X}$ to the regolith (equation (2)) may also be rewritten in terms of the total regolith production rate $P_{r}+P_{d}$ and $f_{d}$.

$$
P_{\mathrm{X}}=\left(1-f_{d}\right)\left(P_{r}+P_{d}\right) \mathrm{X}_{r}+f_{d}\left(P_{r}+P_{d}\right) \mathrm{X}_{d}
$$

Next we invoke the chemical immobility of two elements (here $\mathrm{Zr}$ and Ti). If both $\mathrm{Zr}$ and Ti are immobile, then $W_{\mathrm{Zr}}=0$ and $W_{\mathrm{Ti}}=0$, which when substituted into equation (2) yield equations (9) and (10).

$$
\begin{aligned}
& P_{\mathrm{Zr}}=E \mathrm{Zr}_{s} \\
& P_{\mathrm{Ti}}=E \mathrm{Ti}_{s}
\end{aligned}
$$

Equations (9) and (10), in conjunction with equation (8), yield two independent expressions for the physical erosion rate $E$.

$$
\begin{aligned}
& E=\left(P_{r}+P_{d}\right)\left[\left(1-f_{d}\right) \frac{\mathrm{Zr}_{r}}{\mathrm{Zr}_{s}}+f_{d} \frac{\mathrm{Zr}_{d}}{\mathrm{Zr}_{s}}\right] \\
& E=\left(P_{r}+P_{d}\right)\left[\left(1-f_{d}\right) \frac{\mathrm{Ti}_{r}}{\mathrm{Ti}_{s}}+f_{d} \frac{\mathrm{Ti}_{d}}{\mathrm{Ti}_{s}}\right]
\end{aligned}
$$

Setting equations (11) and (12) equal to each other permits calculation of the fraction of the regolith's parent material that was dust, $f_{d}$.

$$
f_{d}=\left(\frac{\mathrm{Ti}_{r}}{\mathrm{Ti}_{s}}-\frac{\mathrm{Zr}_{r}}{\mathrm{Zr}_{s}}\right)\left[\frac{\mathrm{Ti}_{r}-\mathrm{Ti}_{d}}{\mathrm{Ti}_{s}}-\frac{\mathrm{Zr}_{r}-\mathrm{Zr}_{d}}{\mathrm{Zr}_{s}}\right]^{-1}
$$

Note the requirements for calculating $f_{d}$ : one needs the concentrations of two immobile elements in the bedrock, regolith, and dust. The value of $f_{d}$ is the critical quantity in this analysis. It can be substituted into equation (7) to yield the long-term dust incorporation rate $P_{d}$, which can then be substituted into equations (3)-(5) to yield the physical erosion rate and the bulk and elemental chemical erosion rates. This expression for $f_{d}$ is functionally different than a similar expression by Eberly et al. [1996] in which the dust fraction was defined as $M_{d} / M_{s}$, where $M_{d}$ was defined as the mass of dust that was mixed with a mass of rock $M_{r}$ during the development of a unit mass of regolith $M_{s}$. This definition implicitly assumes that all of the rock-derived and dustderived mass that had been added to the regolith is still present in the sampled regolith; i.e., that $M_{r}+M_{d}=M_{s}$. This definition, however, ignores chemical mass losses $M_{w}$ that may have occurred by erosion of solutes during regolith development; that is, it assumes $M_{w}$ is negligible in the full mass balance expression $M_{r}+M_{d}=M_{s}+M_{w}$. Unlike equation (13), therefore, Eberly et al.'s expression is only correct in the limiting and uncommon scenario where chemical weathering losses have been truly negligible during regolith development, and it systematically overestimates the dust fraction where regolith chemical weathering losses have been non-negligible.

[6] As Figure 2 makes clear, equation (13) loses its predictive power in cases where the denominator in equation (13) approaches zero, i.e., in cases where $\left(\mathrm{Ti}_{\mathrm{r}}-\mathrm{Ti}_{\mathrm{d}}\right) / \mathrm{Ti}_{\mathrm{s}}$ approaches $\left(\mathrm{Zr}_{\mathrm{r}}-\mathrm{Zr}_{\mathrm{d}}\right) / \mathrm{Zr}_{\mathrm{s}}$. Aside from that limiting scenario, however, 


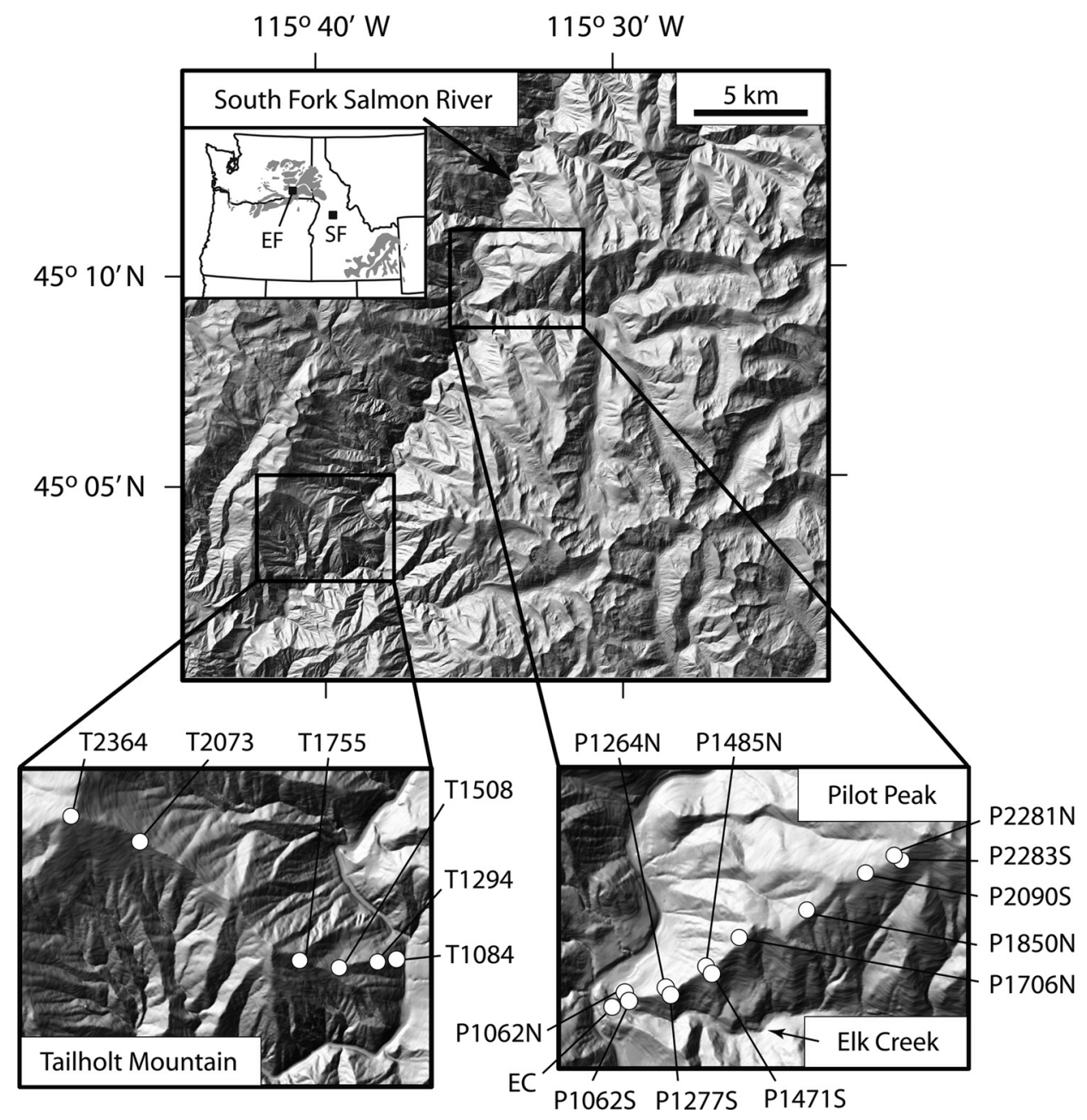

Figure 3. Field sites on Pilot Peak and Tailholt Mountain in the Idaho Batholith, mapped on a 10-m shaded relief DEM. See Table 1 for a list of site characteristics. Inset map of northwestern United States shows the locations of our field sites in the South Fork Salmon River canyon (SF), the proposed dust source Eureka Flat (EF), and the distribution of last glacial loess deposits (gray shaded regions, adapted from Bettis et al. [2003]).

this framework is useful in that it permits calculation of longterm physical and chemical erosion rates in places where dust incorporation is significant without requiring direct physical measurements of long-term dust fluxes. It is also valuable because it is applicable to actively eroding hillslopes; unlike estimating dust fluxes by measuring the thickness of dust deposited over a known time interval, this approach does not require assuming that erosion of the deposited dust has been negligible. It is also valuable because the dust incorporation rates it quantifies provide a long-term baseline against which modern dust fluxes may be compared.

[7] We caution that the usefulness of this approach is likely to be limited to certain field sites. As stated above, this framework rests on the approximation that rates of regolith production and dust incorporation are steady in time, as are the compositions of the rock and dust being incorporated into the regolith; consequently, it will be most accurate in places where deviations from exact steady state are smallest [Ferrier and Kirchner, 2008]. Application of this method also requires that regolith production rates inferred from cosmogenic ${ }^{10} \mathrm{Be}$ in quartz are not affected by ${ }^{10} \mathrm{Be}$ in dust-borne quartz. In practice, standard laboratory procedures avoid this pitfall by analyzing ${ }^{10} \mathrm{Be}$ only in quartz grains $>250$ microns in size, i.e., much larger than the $<50$ micron particles typical of dust [e.g., Reheis, 2006]. This approach also requires the existence of two immobile elements (e.g., $\mathrm{Zr}$ and $\mathrm{Ti}$ ) in the system and the ability to determine their concentrations in dust. In cases where $\mathrm{Zr}$ and $\mathrm{Ti}$ are not equally immobile, differences between enrichments of $\mathrm{Zr}$ and $\mathrm{Ti}$ could be due to preferential losses of one of the elements (e.g., through chemical weathering of Ti-bearing minerals) or exogenous dust influxes or a combination of both. In such settings measurements of $\mathrm{Zr}$ and Ti enrichments alone cannot distinguish between these two causes. Thus, although multiple elements have been found to be equally immobile in several field studies [e.g., Merritts et al., 1992; Kurtz et al., 2000; White et al., 2001; Anderson et al., 2002], it is certainly not possible to apply this framework everywhere. For example, some studies have inferred mobility of $\mathrm{Ti}$ in solution in intensely weathered tropical regolith profiles [e.g., Cornu et al., 1999], while others have suggested that Zr may be preferentially physically mobile due to differences in density and particle size between 
Table 1. Field Site Characteristics, Cosmogenic ${ }^{10}$ Be Concentrations, and Inferred Regolith Production Rates ${ }^{\mathrm{a}}$

\begin{tabular}{|c|c|c|c|c|c|c|c|c|c|}
\hline Site & $\begin{array}{l}\text { Latitude } \\
\left({ }^{\circ} \mathrm{N}\right)\end{array}$ & $\begin{array}{l}\text { Longitude } \\
\left({ }^{\circ} \mathrm{W}\right)\end{array}$ & $\begin{array}{l}\text { Altitude } \\
\text { (m) }\end{array}$ & $\begin{array}{l}\text { Regolith } H(n)^{\mathrm{b}} \\
\quad(\mathrm{cm})\end{array}$ & $\begin{array}{l}\text { Distance to Ridge } \\
(\mathrm{m})^{\mathrm{c}}\end{array}$ & $\begin{array}{l}\text { Slope } \\
\text { (deg) }\end{array}$ & Shielding Factor ${ }^{\mathrm{d}}$ & $\begin{array}{c}{ }^{10} \mathrm{Be} \\
\left(10^{4} \mathrm{at} / \mathrm{g}\right)\end{array}$ & $\begin{array}{c}P_{r} \\
\left(\mathrm{t} \mathrm{km}^{-2} \mathrm{yr}^{-1}\right)\end{array}$ \\
\hline \multicolumn{10}{|c|}{ Pilot Peak } \\
\hline P2283S & $45^{\circ} 10.263^{\prime}$ & $115^{\circ} 31.869^{\prime}$ & 2283 & $50 \pm 4(11)$ & $43-48$ & $20-25$ & 0.989 & $28.7 \pm 0.7$ & $167 \pm 14$ \\
\hline P2281N & $45^{\circ} 10.270^{\prime}$ & $115^{\circ} 31.895^{\prime}$ & 2281 & $16 \pm 6(7)$ & $30-40$ & $20-30$ & 0.996 & $26.3 \pm 0.7$ & $183 \pm 15$ \\
\hline P2090S & $45^{\circ} 10.156^{\prime}$ & $115^{\circ} 32.234^{\prime}$ & 2090 & $57 \pm 5(7)$ & $40-46$ & $15-20$ & 0.996 & $28.3 \pm 0.6$ & $150 \pm 12$ \\
\hline P1850N & $45^{\circ} 09.867^{\prime}$ & $115^{\circ} 32.882^{\prime}$ & 1850 & $29 \pm 5(13)$ & $2-9$ & 25 & 0.988 & $18.8 \pm 0.4$ & $194 \pm 15$ \\
\hline $\mathrm{P} 1706 \mathrm{~N}$ & $45^{\circ} 09.675^{\prime}$ & $115^{\circ} 33.620^{\prime}$ & 1706 & $38 \pm 3(14)$ & $10-16$ & $20-26$ & 0.991 & $20.0 \pm 0.5$ & $166 \pm 13$ \\
\hline P1485N & $45^{\circ} 09.438^{\prime}$ & $115^{\circ} 33.960^{\prime}$ & 1485 & $31 \pm 2(16)$ & $21-27$ & $23-26$ & 0.989 & $31.0 \pm 0.6$ & $91 \pm 7$ \\
\hline P1471S & $45^{\circ} 09.419^{\prime}$ & $115^{\circ} 33.960^{\prime}$ & 1471 & $32 \pm 3(15)$ & $24-30$ & 26 & 0.987 & $29.8 \pm 0.7$ & $94 \pm 7$ \\
\hline P1277S & $45^{\circ} 09.259^{\prime}$ & $115^{\circ} 34.403^{\prime}$ & 1277 & $44 \pm 2(21)$ & $17-26$ & $25-35$ & 0.967 & $14.4 \pm 0.3$ & $171 \pm 13$ \\
\hline $\mathrm{P} 1264 \mathrm{~N}$ & $45^{\circ} 09.276^{\prime}$ & $115^{\circ} 34.406^{\prime}$ & 1264 & $43 \pm 3(20)$ & $9-18$ & 33 & 0.977 & $15.5 \pm 0.4$ & $159 \pm 12$ \\
\hline P1062S & $45^{\circ} 09.228^{\prime}$ & $115^{\circ} 34.924^{\prime}$ & 1062 & $>75(1)$ & $2-7$ & $10-20$ & 0.992 & $29.8 \pm 0.7$ & $71 \pm 5$ \\
\hline P1062N & $45^{\circ} 09.238^{\prime}$ & $115^{\circ} 34.949^{\prime}$ & 1062 & $33 \pm 2(19)$ & $2-6$ & $23-30$ & 0.975 & $37.6 \pm 1.0$ & $55 \pm 4$ \\
\hline \multicolumn{10}{|c|}{ Tailholt Mt. } \\
\hline T2364 & $45^{\circ} 04.867^{\prime}$ & $115^{\circ} 41.654^{\prime}$ & 2364 & $28 \pm 2(10)$ & $27-36$ & $11-16$ & 0.999 & $34.9 \pm 1.2$ & $145 \pm 12$ \\
\hline T2073 & $45^{\circ} 04.657^{\prime}$ & $115^{\circ} 40.896^{\prime}$ & 2073 & $25 \pm 3(7)$ & $0-5$ & 9 & 0.998 & $19.6 \pm 0.5$ & $217 \pm 17$ \\
\hline T1755 & $45^{\circ} 03.688^{\prime}$ & $115^{\circ} 39.095^{\prime}$ & 1755 & $37 \pm 4(13)$ & $5-11$ & $22-27$ & 0.985 & $10.8 \pm 0.2$ & $320 \pm 24$ \\
\hline T1508 & $45^{\circ} 03.632^{\prime}$ & $115^{\circ} 38.651^{\prime}$ & 1508 & $32 \pm 4(16)$ & $1-8$ & 30 & 0.978 & $11.8 \pm 0.2$ & $248 \pm 19$ \\
\hline T1294 & $45^{\circ} 03.674^{\prime}$ & $115^{\circ} 38.226^{\prime}$ & 1294 & $57 \pm 4(15)$ & $55-60$ & $24-39$ & 0.952 & $9.1 \pm 0.2$ & $275 \pm 21$ \\
\hline T1084 & $45^{\circ} 03.682^{\prime}$ & $115^{\circ} 38.016^{\prime}$ & 1084 & $56 \pm 4(12)$ & 400 & $35-40$ & 0.935 & $8.8 \pm 0.2$ & $243 \pm 18$ \\
\hline
\end{tabular}

${ }^{a}$ Regolith production rates $P_{r}$ were calculated with the CRONUS-Earth online denudation rate calculator [Balco et al., 2008], under the steady state assumption that regolith production rates equal denudation rates. Additional inputs to the CRONUS calculator at all sites were assumed to be: sample thickness $0 \mathrm{~cm}$, parent material density $2.7 \mathrm{~g} / \mathrm{cm}^{3}$, and the standard atmospheric scaling. The ${ }^{10}$ Be concentrations were measured at LLNL-CAMS on 15 July 2007 and referenced to isotopic standard 07KNSTD3110.

${ }^{\mathrm{b}}$ Regolith thicknesses $H$ (mean \pm s.e., from $n$ measurements) are vertical distances between the parent rock and the hillslope surface.

${ }^{c}$ Distances are along the hillslope from the regolith sampling plot to the ridgeline in the direction of steepest ascent.

${ }^{\mathrm{d}}$ Topographic shielding factors were calculated with the CRONUS calculator using eight horizon shielding angles measured in the field at azimuths of 0,45 , $90,135,180,225,270$, and 315 degrees.

zircons and the bulk regolith [e.g., Taboada et al., 2006]. However, we suggest that in many environments, especially temperate climates where chemical weathering should be weak, multiple elements should be immobile, and it may be possible to use geologic considerations to constrain the probable source of dust and its composition.

\section{Methods: Field Sites and Sample Collection in the Idaho Batholith}

[8] In 2005 we established a series of 17 field sites along two altitudinal transects on Pilot Peak and Tailholt Mountain in central Idaho to investigate controls on long-term chemical and physical erosion rates (Figure 3 and Table 1). Pilot Peak and Tailholt Mountain rise $1500 \mathrm{~m}$ and $1300 \mathrm{~m}$ above the South Fork of the Salmon River over horizontal distances of $5.1 \mathrm{~km}$ and $5.7 \mathrm{~km}$, respectively. Both mountains lie within 87-78 Ma plutons of biotite-muscovite granite and granitegranodiorite in the Idaho Batholith [Lund, 2004]. Neither mountain has mapped faults running through it or obvious field evidence of faulting [Lund, 2004], suggesting that neither mountain should be subject to sharp gradients in rock uplift rates which might produce sharp gradients in physical or chemical erosion rates. No roads cross the altitudinal transects along which our field sites are located (Figure 3), suggesting that anthropogenic disturbance across each transect has been minimal. At most elevations on both transects, ponderosa pine and Idaho bluebunch grasses dominate the vegetation, which grows in the thin soils $(10-90 \mathrm{~cm})$ mantling the hillslopes. Large $(>1 \mathrm{~m})$ granitic outcrops are common on the study transects and are more common on ridgelines than on hillslopes, with a spatial frequency that is highly variable.
A randomly chosen patch of ridgeline with an area of $10 \mathrm{~m}$ by $10 \mathrm{~m}$, for example, might contain no outcrops at all (and this would be the case for most segments of the study transects), but a few places on the study transects are marked by outcrops that are clustered closely together, and a $10 \mathrm{~m}$ by $10 \mathrm{~m}$ patch of ridgeline at these locations would consist almost entirely of outcrops. Variations in climate are large across these transects: an expected moist atmospheric lapse rate of $5-6^{\circ} \mathrm{C} / \mathrm{km}$ implies that the mean annual air temperature at the summits should be $8-9^{\circ} \mathrm{C}$ cooler than at the South Fork of the Salmon River, at the base of both transects. Because these altitudinal transects are home to large climatic variations and small nonclimatic variations, these field sites offer an opportunity to isolate climatic effects on chemical erosion rates [Ferrier, 2009], which is the subject of a future companion paper. In the present paper, we restrict our attention to showing how equations (7) and (13) may be used to estimate dust incorporation rates at these field sites.

[9] Because practical application of the mass balance approach (section 2) at any given site requires measurements of the mean concentrations of the eroding regolith and its parent rock, and because in nature rock and regolith have spatially variable compositions, we collected groups of rock and regolith samples at each site (Figure 3 and Table 1) and averaged their compositions to estimate the mean compositions of rock and regolith at each site (Tables S1-S6 in the auxiliary material). ${ }^{1}$ Field site locations were chosen to be on or close to ridgelines to minimize variations in regolith

\footnotetext{
${ }^{1}$ Auxiliary materials are available in the HTML. doi:10.1029/
} 2011JF001991. 
chemistry that can arise during downslope regolith transport [e.g., Green et al., 2006; Yoo et al., 2007]. All field sites lie 0$60 \mathrm{~m}$ from the ridge in the direction of steepest ascent, with the exception of site T1084, which lies near the base of a roughly planar hillslope at the toe of Tailholt Mountain and which is $400 \mathrm{~m}$ downslope of the nearest ridgeline (Figure 3 and Table 1). At each field site we collected 16 regolith samples within a $\sim 10 \mathrm{~m}$ by $10 \mathrm{~m}$ plot to quantify horizontal variations in regolith composition and to minimize uncertainties in mean regolith composition. Each of these samples was collected at a depth of $10-15 \mathrm{~cm}$, roughly the rooting depth of the bunch grasses. The absence of systematic vertical variations in regolith $\mathrm{Ti}$ and $\mathrm{Zr}$ concentrations at our field sites (described below; see also Figures S2-S18) suggest that the regolith samples we collected at 10-15 cm depth should be representative of the physically eroding regolith, which is what the mass balance method requires. These sixteen regolith samples are the samples from which mean regolith compositions were calculated at each site (Tables S4 and S6). In addition to the 16 horizontally distributed regolith samples at each site, within each plot we also collected a vertical series of samples from a single soil pit to measure vertical variations in composition within the regolith profile (Figures S2-S18). During a second field visit in 2006, we dug multiple pits down to the parent rock at each field site to measure regolith thickness (Table 1). To quantify the composition of the parent rock, we collected 40 granite samples at each site from outcrops within $50 \mathrm{~m}$ upslope of the regolith sampling plots. Because outcrops in the regolith sampling plots compose only $0-5 \%$ of the plot area, most outcrop samples were collected upslope of the sampled regoliths rather than within the regolith plots themselves. In total, we collected 916 rock and regolith samples across the 17 field sites. From this suite of rock and regolith samples we measured regolith production rates from cosmogenic ${ }^{10} \mathrm{Be}$ in regolith-borne quartz and the mean chemical compositions of the regolith and its parent rock at each field site. Here we describe the laboratory procedures for chemical and isotopic analysis of these samples.

\section{Methods: Sample Preparation}

[10] At each field site we estimated the mean chemical composition of the regolith and its parent rock by averaging the chemical composition of 16 regolith samples and 40 rock samples. All rock and regolith samples were prepared for chemical analysis by X-ray fluorescence by standard procedures [Riebe, 2000]. All samples were split, and about $30 \mathrm{~g}$ of one of the splits was powdered in a tungsten carbide Spex shatterbox. Powdered samples were then baked at $500^{\circ} \mathrm{C}$ for $12 \mathrm{~h}$ to eliminate organic material. At this point, two sets of samples were prepared, one for major element chemistry and one for trace element chemistry. Major element samples were prepared by mixing $3.5000 \pm 0.0001 \mathrm{~g}$ of lithium tetraborate with $0.5000 \pm 0.0001 \mathrm{~g}$ of powdered sample, homogenizing this powder in a shaker for $15 \mathrm{~min}$, melting the mixed powders in a platinum crucible above a Bunsen burner flame for $10 \mathrm{~min}$, and pouring the melted mixture into a platinum tray. This yielded glass disks roughly $33 \mathrm{~mm}$ in diameter and $2 \mathrm{~mm}$ thick. Trace element samples were prepared by mixing $3.3 \pm$ $0.1 \mathrm{~g}$ of powdered sample with five drops of polyvinyl alcohol and pressing the mixed powder into a pellet with a boric acid backing. Both trace element pellets and major element disks were then analyzed for elemental abundances on a Phillips 2400R X-ray fluorescence spectrometer. The chemistry of all 916 samples are listed in Tables S1 and S2, and Tables S3-S6 summarize the mean chemical compositions of rock and regolith at each site.

[11] Regolith production rates were inferred from concentrations of ${ }^{10} \mathrm{Be}$ in quartz extracted from amalgamated regolith samples at each site. From each of the sixteen nearsurface regolith samples (i.e., those collected at a depth of 10 $15 \mathrm{~cm}$ ) at each site, we split approximately $150 \mathrm{~g}$ of regolith, and mixed these splits together. These amalgamated regolith samples were themselves split, and from one of these splits $39-55 \mathrm{~g}$ of quartz was isolated from the $>250$ micron size fraction by standard magnetic and chemical separations [Kohl and Nishiizumi, 1992; Riebe, 2000]. These quartz samples were spiked with known amounts of ${ }^{9} \mathrm{Be}$ in solution, after which they were dissolved in a mixture of hydrofluoric and nitric acids, dried down in platinum crucibles, redissolved in sulfuric acid, dried down a second time, and redissolved in hydrochloric acid. Beryllium was then isolated from other elements in cation exchange columns and precipitated as beryllium hydroxide by raising the $\mathrm{pH}$ of the solution to 8 with ammonium hydroxide. Beryllium hydroxide was isolated from solution by centrifugation, placed in quartz crucibles, and baked at $750^{\circ} \mathrm{C}$ to oxidize the material to $\mathrm{BeO}$. Each $\mathrm{BeO}$ sample was then mixed with niobium powder and packed into stainless steel sample holders for measurement at the Center for Accelerator Mass Spectrometry at Lawrence Livermore National Laboratory. Regolith production rates inferred from cosmogenic ${ }^{10} \mathrm{Be}$ are listed in Table 1.

\section{Chemical Evidence for Mafic Dust Incorporation in Idaho Batholith Regoliths}

[12] Several characteristics of the rock and regolith compositions at our field sites suggest that mafic material has been added to the otherwise granitic regoliths. First, the rock-to-regolith enrichments of the elements most commonly assumed to be immobile ( $\mathrm{Zr}$ and $\mathrm{Ti}$ ) are quite different from one another, whereas they should be identical if both $\mathrm{Zr}$ and Ti were immobile and derived from the underlying rock alone. Second, the differences in $\mathrm{Ti}$ and $\mathrm{Zr}$ enrichment are systematic: At all of the field sites except one, enrichments of $\mathrm{Ti}$ are higher than $\mathrm{Zr}$ enrichments. If dust incorporation rates were ignored in equation (4) (as is often done [Riebe et al., 2001, 2003, 2004a, 2004b; Green et al., 2006; Burke et al., 2007, 2009; Dixon et al., 2009a, 2009b]), estimates of $W$ at our sites would be, on average, over twice as high when estimated with Ti than with $\mathrm{Zr}$ (Figures 4 and 5). Such differences in rock-to-regolith enrichments between immobile elements are not unique to these field sites. Indeed, it is more common in the literature to find disagreements in rock-toregolith enrichments between different immobile elements [e.g., Green et al., 2006] than agreements [e.g., Anderson et al., 2002], suggesting that dust may play a significant role in setting regolith composition in many places. Third, at many of our field sites rock-to-regolith enrichments of several elements that are usually considered to be mobile $(\mathrm{Mg}$, $\mathrm{Fe}$, and $\mathrm{Mn}$ ) are higher than those for presumably immobile $\mathrm{Zr}$ (Figure S21). 


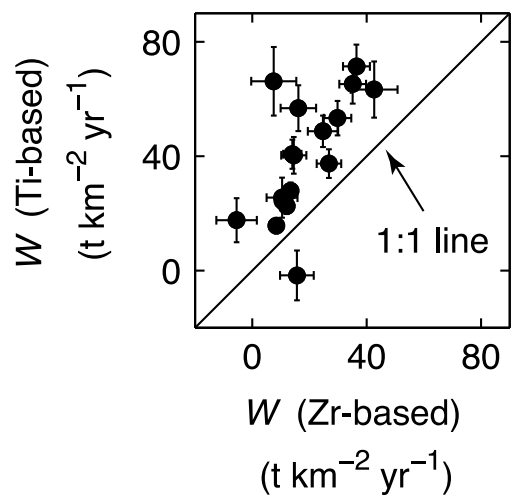

Figure 4. Estimates of chemical erosion rates $W$ at our Idaho field sites, calculated with equation (4) under the assumption that dust incorporation rates are negligible (i.e., $P_{d}=0$ ). $\mathrm{Y}$-coordinates for these data points were calculated using $\mathrm{Ti}$ as the lone immobile tracer in equation (4), and $\mathrm{x}$-coordinates were calculated using $\mathrm{Zr}$ as the lone immobile tracer. This figure suggests that if dust incorporation rates were neglected at our field sites, then Ti-based estimates of chemical erosion rates would be, on average, over twice as high as Zr-based estimates. However, if $\mathrm{Zr}$ and $\mathrm{Ti}$ are both immobile and if dust incorporation rates are truly negligible, then $\mathrm{Zr}$-based estimates of $W$ should be identical to Ti-based estimates of $W$, and data points in this plot should lie along the 1:1 line. This systematic discrepancy suggests either that Ti-rich material has been added to the sampled regoliths or that $\mathrm{Zr}$ is mobile relative to $\mathrm{Ti}$.

[13] We suggest that the simplest explanation for these observations is incorporation of mafic-rich dust. Other explanations are theoretically possible, but we consider these less likely than dust incorporation. For example, the Idaho Batholith is intruded by infrequent dacite dikes rich in $\mathrm{Ti}, \mathrm{Fe}$, and $\mathrm{Mg}$ [Lund, 2004; K. Lund, personal communication, 2009]. Could the incorporation of dacitic bedrock into the sampled regoliths be responsible for the excess enrichment of mafic elements at all of our field sites? For this to be the case, dacite would have to be part of the regolith's parent rock at every field site. We found no evidence that would support this. We found no mafic outcrops at or upslope of any of the sampled regoliths, and we found no mafic bedrock at the base of any of the regolith pits we dug at any of the field sites. Although we observed rare surface exposures of dacite elsewhere on the mountains where the field sites are located, all of our field sites are at least hundreds of meters from (and not downslope of) such exposures. Thus the absence of mafic bedrock and outcrops at any of the field sites suggests it is unlikely that dacite was incorporated from bedrock into the sampled regolith at any of the field sites, and even less likely that it could be responsible for the systematic enrichment of mafic elements across all of the field sites. It is also theoretically possible to explain the lower rock-to-regolith enrichments of $\mathrm{Zr}$ relative to those of $\mathrm{Ti}, \mathrm{Fe}, \mathrm{Mn}$, and $\mathrm{Mg}$ by arguing that $\mathrm{Zr}$ is more mobile than $\mathrm{Ti}, \mathrm{Fe}, \mathrm{Mn}$, and $\mathrm{Mg}$ at these field sites. This, however, is geochemically implausible. $\mathrm{Zr}$ in granites is found almost entirely in zircon, and prior work suggests that $\mathrm{Zr}$ should not be more mobile than $\mathrm{Ti}, \mathrm{Fe}, \mathrm{Mn}$, or
$\mathrm{Mg}$ [e.g., Hodson, 2002]. Thus, rather than suggest that $\mathrm{Ti}$, $\mathrm{Fe}, \mathrm{Mn}$, and $\mathrm{Mg}$ are somehow more immobile than $\mathrm{Zr}$ at these field sites, we instead favor the hypothesis that dust rich in these elements has been added to the sampled regoliths.

\section{Eureka Flat: A Proposed Dust Source to the Canyon of the South Fork of the Salmon River}

[14] There are, to our knowledge, no direct measurements of dust fluxes or dust composition in the South Fork of the Salmon River canyon. This precludes the definitive calculation of long-term chemical and physical erosion rates at these field sites with equations (3)-(5). However, it is possible to constrain probable dust compositions using published values from the literature, and to use those compositions to estimate long-term dust incorporation rates at our field sites using equation (7).

[15] We consider the most probable source of mafic dust to the Idaho Batholith to be the huge Palouse loess fields on the Columbia Plateau. The Palouse loess extends over $>50,000 \mathrm{~km}^{2}$ of southeastern Washington, northeastern Oregon, and northwestern Idaho, and its eastern edge lies within $100 \mathrm{~km}$ of Pilot Peak (Figure 3). The upper unit of the Palouse loess, which has been deposited over the past $15 \mathrm{kyr}$, is as much as $4.5 \mathrm{~m}$ thick [e.g., Bryan, 1927; Busacca et al., 1992, 2004; Sweeney et al., 2007]. Eureka Flat, an 80-km long deflationary plain $275 \mathrm{~km}$ WNW of our field sites in the South Fork of the Salmon River, has been proposed as the primary source of the Palouse loess on the basis of chemical and textural similarities between the loess and the glacial
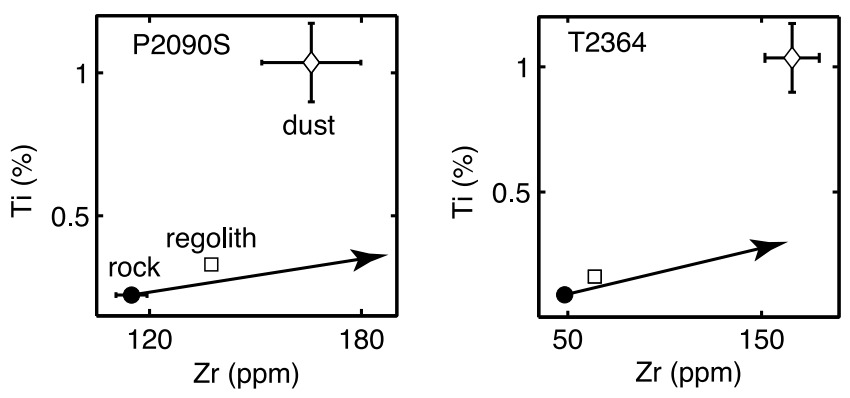

Figure 5. As an illustration of the effects of adding Ti-rich dust to the sampled regoliths, in this figure we show Ti and $\mathrm{Zr}$ concentrations in the rock (filled circles), regolith (open squares), and the proposed dust source (open diamonds) [Sweeney et al., 2007] (Table S6) at two representative field sites (P2090S and T2364; Table 2). The arrow in each plot lies on a line that passes through the plot's origin $(0,0)$ and the rock composition, and indicates the evolution of regolith composition that would be expected if dust incorporation were negligible and if $\mathrm{Zr}$ and $\mathrm{Ti}$ were equally immobile during chemical weathering. The deviation of the measured regolith composition from the expected chemical evolution vector suggests either that Ti-rich material has been added to the sampled regolith (e.g., from the proposed dust source) or that $\mathrm{Zr}$ is mobile relative to Ti. Similar plots for all 17 field sites are shown in the auxiliary material (Figure S1), and reveal that regoliths at 16 of the 17 sites show similar excesses of Ti relative to $\mathrm{Zr}$ (Table 1). 
Table 2. $\mathrm{Zr}$ and Ti Concentrations in Rock and Regolith at the Study Sites and Estimates of Dust Incorporation Rates $P_{d}^{a}$

\begin{tabular}{|c|c|c|c|c|c|c|c|}
\hline \multirow[b]{2}{*}{ Site ID } & \multicolumn{2}{|c|}{$\mathrm{Zr}(\mathrm{ppm})$} & \multicolumn{2}{|c|}{$\mathrm{Ti}(\%)$} & \multirow[b]{2}{*}{$\mathrm{Ti}_{\mathrm{r}} / \mathrm{Zr}_{\mathrm{r}}$} & \multirow[b]{2}{*}{$f_{d}(\%)$} & \multirow[b]{2}{*}{$P_{d}\left(\mathrm{t} \mathrm{km}^{-2} \mathrm{yr}^{-1}\right)$} \\
\hline & Rock & Regolith & Rock & Regolith & & & \\
\hline $\mathrm{P} 2283 \mathrm{~S}$ & $117.0 \pm 3.0$ & $139.4 \pm 1.1$ & $0.231 \pm 0.006$ & $0.298 \pm 0.005$ & $19.7 \pm 0.7$ & $2.7 \pm 1.0$ & $4.7 \pm 1.8$ \\
\hline $\mathrm{P} 2281 \mathrm{~N}$ & $117.0 \pm 3.0$ & $139.8 \pm 1.2$ & $0.231 \pm 0.006$ & $0.326 \pm 0.006$ & $19.7 \pm 0.7$ & $6.1 \pm 1.4$ & $11.9 \pm 3.1$ \\
\hline P2090S & $114.9 \pm 4.4$ & $137.5 \pm 1.0$ & $0.223 \pm 0.008$ & $0.330 \pm 0.005$ & $19.4 \pm 1.0$ & $7.7 \pm 1.5$ & $12.6 \pm 2.8$ \\
\hline $\mathrm{P} 1850 \mathrm{~N}$ & $123.2 \pm 3.1$ & $119.8 \pm 3.0$ & $0.220 \pm 0.006$ & $0.242 \pm 0.008$ & $17.9 \pm 0.7$ & $4.0 \pm 1.2$ & $8.0 \pm 2.5$ \\
\hline $\mathrm{P} 1706 \mathrm{~N}$ & $122.8 \pm 3.3$ & $134.5 \pm 0.9$ & $0.200 \pm 0.008$ & $0.264 \pm 0.005$ & $16.3 \pm 0.8$ & $5.4 \pm 1.3$ & $9.5 \pm 2.5$ \\
\hline $\mathrm{P} 1485 \mathrm{~N}$ & $126.9 \pm 3.2$ & $148.8 \pm 1.3$ & $0.224 \pm 0.006$ & $0.323 \pm 0.005$ & $17.7 \pm 0.6$ & $7.0 \pm 1.2$ & $6.9 \pm 1.4$ \\
\hline P1471S & $126.9 \pm 3.2$ & $139.4 \pm 1.4$ & $0.224 \pm 0.006$ & $0.269 \pm 0.004$ & $17.7 \pm 0.6$ & $2.8 \pm 0.7$ & $2.7 \pm 0.7$ \\
\hline P1277S & $118.6 \pm 4.1$ & $130.5 \pm 1.9$ & $0.204 \pm 0.009$ & $0.202 \pm 0.005$ & $17.2 \pm 1.0$ & $-2.7 \pm 0.9$ & $-4.5 \pm 1.5$ \\
\hline $\mathrm{P} 1264 \mathrm{~N}$ & $118.6 \pm 4.1$ & $126.9 \pm 1.3$ & $0.204 \pm 0.009$ & $0.243 \pm 0.006$ & $17.2 \pm 1.0$ & $3.1 \pm 1.0$ & $5.1 \pm 1.7$ \\
\hline P1062S & $129.5 \pm 1.6$ & $155.9 \pm 2.9$ & $0.220 \pm 0.003$ & $0.323 \pm 0.013$ & $17.0 \pm 0.3$ & $6.5 \pm 1.3$ & $4.9 \pm 1.1$ \\
\hline $\mathrm{P} 1062 \mathrm{~N}$ & $129.5 \pm 1.6$ & $160.8 \pm 1.3$ & $0.220 \pm 0.003$ & $0.399 \pm 0.007$ & $17.0 \pm 0.3$ & $13.9 \pm 2.2$ & $8.8 \pm 1.7$ \\
\hline $\mathrm{T} 2364$ & $48.4 \pm 1.1$ & $63.9 \pm 1.5$ & $0.089 \pm 0.003$ & $0.162 \pm 0.006$ & $18.4 \pm 0.7$ & $5.1 \pm 1.1$ & $7.8 \pm 1.9$ \\
\hline T2073 & $82.5 \pm 0.9$ & $88.2 \pm 0.9$ & $0.143 \pm 0.002$ & $0.176 \pm 0.003$ & $17.3 \pm 0.3$ & $2.9 \pm 0.7$ & $6.5 \pm 1.6$ \\
\hline $\mathrm{T} 1755$ & $75.5 \pm 1.5$ & $77.3 \pm 1.2$ & $0.119 \pm 0.004$ & $0.150 \pm 0.004$ & $15.8 \pm 0.6$ & $3.6 \pm 0.7$ & $12.0 \pm 2.7$ \\
\hline $\mathrm{T} 1508$ & $70.3 \pm 1.6$ & $75.2 \pm 1.0$ & $0.121 \pm 0.003$ & $0.157 \pm 0.004$ & $17.2 \pm 0.6$ & $3.6 \pm 0.8$ & $9.1 \pm 2.2$ \\
\hline T1294 & $58.4 \pm 1.8$ & $69.1 \pm 0.7$ & $0.107 \pm 0.003$ & $0.139 \pm 0.004$ & $18.3 \pm 0.8$ & $1.5 \pm 0.7$ & $4.2 \pm 2.1$ \\
\hline $\mathrm{T} 1084$ & $61.3 \pm 0.8$ & $72.1 \pm 1.0$ & $0.108 \pm 0.002$ & $0.153 \pm 0.004$ & $17.6 \pm 0.4$ & $3.1 \pm 0.7$ & $7.7 \pm 1.8$ \\
\hline
\end{tabular}

aThe fraction of the regolith's parent material derived from dust, $f_{d}$, was calculated with equation (13) under the assumption that the measured regolith compositions (Tables S4 and S6) are a mixture of the sampled granite (Tables S3 and S5) and mafic dust from the Palouse loess $(\mathrm{Zr}=165.8 \pm 14.0 \mathrm{ppm}, \mathrm{Ti}=$ $1.036 \pm 0.137 \% ; \mathrm{Ti} / \mathrm{Zr}=62 \pm 10$ [Sweeney et al., 2007] (Table S6)). Dust incorporation rates $P_{d}$ were calculated with equation (7) from these estimates of $f_{d}$ and regolith production rates $P_{r}$ (Table 1). Rock compositions at sites T2364 and T1755 were calculated using subsets of the rock samples collected at these sites; see auxiliary material for details. All uncertainties in this table are standard errors.

outburst flood sediments blanketing Eureka Flat [Sweeney et al., 2007]. The sediments in Eureka Flat are of mixed grain size (primarily silt, sand, and clay), containing abundant material eroded from the Columbia Plateau basalt during repeated glacial outburst floods over the last ice age. XRF measurements show that the sediments are richer in $\mathrm{Mg}, \mathrm{Ti}$, and $\mathrm{Fe}$ than the granites at Pilot Peak and Tailholt Mountain are (Tables $\mathrm{S} 5$ and $\mathrm{S} 6)$, and have a $\mathrm{Ti} / \mathrm{Zr}$ ratio of $62 \pm 10(\mathrm{Zr}=$ $165.8 \pm 14.0 \mathrm{ppm}, \mathrm{Ti}=1.036 \pm 0.137 \%$ [Sweeney et al. 2007]), which is 3.2-4.0 times higher than the $\mathrm{Ti} / \mathrm{Zr}$ ratios in the granite at our Idaho field sites (Table 2). Wind measurements in Pasco, Washington $(<10 \mathrm{~km}$ west of Eureka Flat) show that although the mean annual wind direction is toward the northeast, not southeast toward our field sites, the mean monthly wind direction is indeed to the southeast during December, January, and February and to the south-southeast during September (http://www.wrcc.dri.edu/ htmlfiles/westwinddir.html; referenced 4 May 2011). Thus we suggest that seasonal variations in wind direction could be responsible for the transport of dust from the Palouse loess to the study sites in the South Fork Salmon River canyon.

[16] Below we calculate $f_{d}$ and $P_{d}$ at the study sites under the assumption that the Palouse loess was the source of mafic dust to the study regoliths, and we take the composition of the flood sediments in Eureka Flat [Sweeney et al., 2007] as representative of the material in the Palouse loess. This approach is not intended to prove that Eureka Flat is the sole source of dust to the study sites; such a proof would require records of dust fluxes and composition in the South Fork of the Salmon River canyon over the regolith residence times, and such records are unavailable at these field sites. Instead, the purpose of this approach is to calculate estimates of $f_{d}$ and $P_{d}$ using the composition of the dust that we suggest is most likely to have been transported to the study sites, given the proximity of the Palouse loess to the study sites and Eureka Flat's history as a major dust source within the Palouse loess. The Palouse loess, of course, is not the only possible atmospheric source of minerals to our field sites.
Central Idaho lies downwind of the Oregon Cascades, which have intermittently ejected large quantities of material into the atmosphere. During the Holocene, the largest Cascadia eruption was at Mt. Mazama, where $50 \mathrm{~km}^{3}$ of material was thrown into the atmosphere roughly $7.7 \mathrm{ka}$ [Bacon and Lanphere, 2006]. Mt. Mazama, however, cannot be the source of mafic-rich elements at our field sites, since the Mazama tephra has a $\mathrm{Ti} / \mathrm{Zr}$ ratio of $16.6 \pm 0.4$ [Bacon and Druitt, 1988], similar to the sampled granite, which has $\mathrm{Ti} / \mathrm{Zr}$ ratios that range from $15.8 \pm 0.6$ to $19.7 \pm 0.7$ (Table 2). Deposition of Mazama tephra thus could not have produced the observed differences between rock-to-regolith enrichments of Ti and $\mathrm{Zr}$ at our field sites. A second possible source of dust that we consider unlikely to have affected the sampled regoliths is the Snake River Plain in southern Idaho. Although there are large loess fields in southern and southeastern Idaho (Figure 3) [Bettis et al., 2003], winds across the Snake River Plain throughout the year are not directed toward the interior of the Idaho Batholith where the study sites lie (see wind data for Boise AP, Burley AP, Caldwell Airport, Idaho Falls AP, Jerome Airport, Mountain Home AFB, Pocatello AP, Rexburg AP, and Twin Falls AP at http://www.wrcc.dri.edu/ htmlfiles/westwinddir.html\#IDAHO; referenced 4 May 2011). Thus we consider the Snake River Plain unlikely to be the primary source of mafic dust to the study sites.

\section{Estimated Dust Incorporation Rates}

[17] Operating under the assumption that the same material that formed the Palouse loess also supplied dust of identical composition to our field sites, we calculate the dust-derived fraction of the regolith's parent material, $f_{d}$, and the long-term dust incorporation rate $P_{d}$ using equations (13) and (7). These calculations show that the regoliths are dominantly derived from the underlying granite (the error-weighted mean and standard error of $f_{d}$ is $3.3 \pm 0.6 \%$ ), and imply long-term mean dust incorporation rates of $5.0 \pm 0.9 \mathrm{t} \mathrm{km}^{-2} \mathrm{yr}^{-1}$ (errorweighted mean and standard error; Figure 6). At all of the 


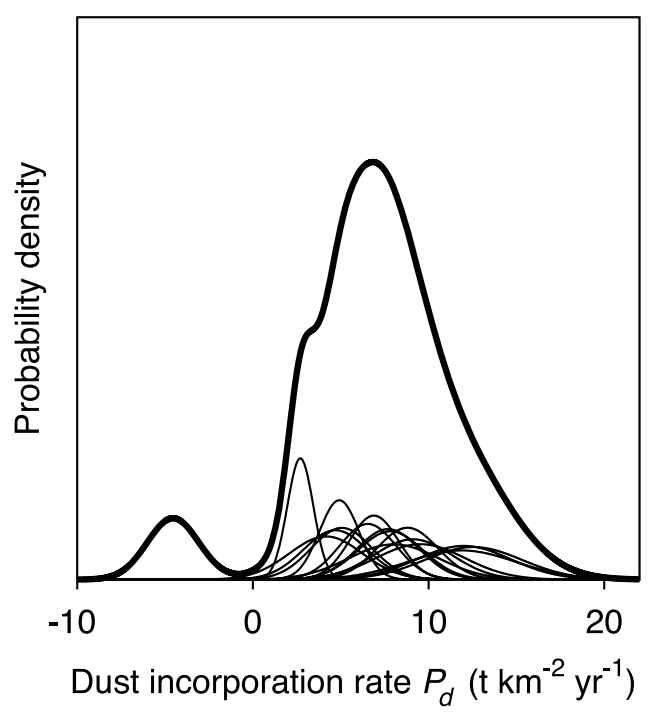

Figure 6. Probability density functions (PDF) for dust incorporation rates $P_{d}$ estimated with equation (7). Each thin line shows a Gaussian PDF of the estimated $P_{d}$ at one of the 17 field sites (Table 2), and is normalized such that the integrated probability under the curve is 1 . Each of these PDFs is centered at the mean $P_{d}$ and has a standard deviation given by the uncertainty in $P_{d}$. The uncertainty in $P_{d}$ at each site was calculated by propagating uncertainties in each of the terms in equation (7), i.e., uncertainties in regolith composition (a consequence of compositional variability among the sixteen regolith samples at each site); rock composition (due to compositional variability among the 40 rock samples at each site); dust composition [Sweeney et al., 2007]; and regolith production rate. The thick line is the sum of these PDFs across all field sites. The group of 17 sites has an error-weighted mean and standard error of $P_{d}=5.0 \pm 0.9 \mathrm{t} \mathrm{km}^{-2} \mathrm{yr}^{-1}$, which rises to $P_{d}=5.8 \pm 0.7 \mathrm{t} \mathrm{km}^{-2} \mathrm{yr}^{-1}$ if the single site with a negative calculated dust incorporation rate $(\mathrm{P} 1277 \mathrm{~S}$; see section 7$)$ is excluded from the calculation of the mean $P_{d}$.

17 field sites except one (discussed below), calculated dust incorporation rates range from 3 to $13 \mathrm{t} \mathrm{km}^{-2} \mathrm{yr}^{-1}$. These are comparable to dust fluxes of 2-20 t km $\mathrm{yr}^{-1}$ measured elsewhere in the western United States [Reheis et al., 1995; Reheis and Kihl, 1995; Reheis, 2006], which suggests that the calculated dust incorporation rates at our field sites are not implausibly high. We note that even if the Palouse loess is not the source of mafic material to our field sites, these calculations demonstrate that dust fluxes can markedly affect regolith composition even when dust fluxes are small relative to hillslope erosion fluxes. We note also that these estimates are calculated within the context of a steady state modeling framework, and the extent to which $P_{r}, P_{d}, X_{r}$, and $X_{d}$ have deviated from steady state over time are not known at the study sites. However, numerical modeling results suggest that regolith chemistry should respond sluggishly to fluctuations in mass fluxes into and out of the regolith, and that fluctuations in regolith chemistry (and hence fluctuations in parameters determined from regolith chemistry) should be much smaller than fluctuations in regolith mass fluxes [Ferrier and Kirchner, 2008]. Thus, to the extent that the composition of the proposed dust source approximates the mean composition of the dust that fell on the sampled regoliths, the estimates of $P_{r}$ should be reasonable approximations of the true dust incorporation rates at these field sites, even if the composition of the falling dust fluctuated over time.

[18] As Table 2 shows, equation (13) yields an impossible result for one site (P1277S). This is the only field site where the rock-to-regolith enrichment of $\mathrm{Ti}$ is smaller than that of $\mathrm{Zr}$, and which therefore does not fit the hypothesis that Ti-rich dust has been incorporated into the regolith at this site. Applying the dust model to site P1277S with the proposed dust source yields the impossible result that less than $0 \%$ of the regolith is derived from dust $\left(f_{d}=-2.7 \pm 0.9 \%\right.$; equation (13)), which itself produces a negative calculated dust flux $\left(P_{d}=-4.5 \pm 1.5 \mathrm{t} \mathrm{km}^{-2} \mathrm{yr}^{-1}\right.$; equation (7)). Thus site $\mathrm{P} 1277 \mathrm{~S}$, alone among the 17 field sites, does not fit the proposed dust model with the proposed dust source. It is not immediately clear why P1277S differs from all the other sites in this respect. However, it is notable that although the rock sample composition at this site is not unusual for rocks at the other ten field sites on Pilot Peak, the P1277S regolith samples are on one end of the compositional spectrum for the Pilot Peak regoliths, with more Si and less $\mathrm{Al}, \mathrm{Fe}, \mathrm{Ti}, \mathrm{Mg}, \mathrm{Nb}$, and $\mathrm{Rb}$ than all other Pilot Peak regoliths (Tables S3-S4). This suggests that the rock samples collected on the ridgeline near site P1277S may be a poor reflection of the parent granite of the P1277S regolith.

\section{Conclusions}

[19] The primary purpose of this paper is to present a simple model for estimating long-term dust incorporation rates to regolith in actively eroding terrain. We show that it may be used to infer long-term average rates of dust incorporation from measurements of regolith production rates and concentrations of two immobile elements (e.g., $\mathrm{Zr}$ and $\mathrm{Ti}$ ) in the regolith, parent bedrock, and dust. This is, at its core, a steady state model. Although the model cannot capture any shortterm variability in dust incorporation rates, the estimated dust incorporation rates it yields may be considered long-term average rates, which can be compared with contemporary measurements of dust deposition to estimate the effects of climate change and human activity on dust production and deposition. This is a complementary approach to other methods for estimating long-term dust fluxes, such as measuring the thickness and ages of loess deposits [e.g., Busacca et al., 2004], or attributing imbalances in $\mathrm{Sr}$ isotope fluxes into and out of catchments to dust deposition [Pett-Ridge et al., 2009].

[20] We emphasize that our application of this method in the South Fork of the Salmon River canyon is not a definitive test of the method nor of the proposed dust source. A definitive test would require direct measurements of dust flux and composition, which are unavailable over the long timescales intrinsic to the approach outlined here. However, given that Eureka Flat has been a persistent source of massive amounts of mafic dust to nearby sites [Sweeney et al., 2007], and that the magnitude of dust incorporation rates we estimate below are consistent with dust fluxes measured elsewhere in the western United States [Reheis et al., 1995; Reheis and Kihl, 1995; Reheis, 2006], we suggest that the Palouse loess is a plausible source of dust and that this is a reasonable approach for estimating long-term dust incorporation rates at our field 
sites. We suggest this approach may provide a practical tool for estimating long-term dust incorporation rates into actively eroding regolith, and thus can help quantify aeolian inputs to biogeochemical cycles in a variety of field settings.

[21] Acknowledgments. This work was supported by NSF grant EAR-0643129, and K.L.F. was supported by a Lawrence Scholar Graduate Fellowship at Lawrence Livermore National Laboratory during this study. We thank Marith Reheis, one anonymous reviewer, and Associate Editor Simon Mudd for insights that substantially improved this manuscript; Jean Dixon for helpful comments on an earlier version of this manuscript; Cliff Riebe for many fruitful discussions; and Alex Densmore and Simon Mudd for shepherding this manuscript through the review process. We are also grateful to the U.S. Forest Service for assistance with field access and forest fire avoidance; Michael Ferrier, Marisa Palucis, and Leslie Hsu for field assistance; and Tim Teague, Ajay Limaye, Shreya Ramesh, Greg Nishimura, and Evan Kha for laboratory assistance.

\section{References}

Anderson, S. P., W. E. Dietrich, and G. H. Brimhall (2002), Weathering profiles, mass-balance analysis, and rates of solute loss: Linkages between weathering and erosion in a small, steep catchment, Geol. Soc. Am. Bull., 114(9), 1143-1158.

Bacon, C. R., and T. H. Druitt (1988), Compositional evolution of the zoned calcalkaline magma chamber of Mount Mazama, Crater Lake, Oregon, Contrib. Mineral. Petrol., 98, 224-256, doi:10.1007/ BF00402114.

Bacon, C. R., and M. A. Lanphere (2006), Eruptive history and geochronology of Mount Mazama and the Crater Lake region, Oregon, Geol. Soc. Am. Bull., 118(11-12), 1331-1359, doi:10.1130/B25906.1.

Balco, G., J. O. Stone, N. A. Lifton, and T. J. Dunai (2008), A complete and easily accessible means of calculating surface exposure ages or erosion rates from ${ }^{10} \mathrm{Be}$ and ${ }^{26} \mathrm{Al}$ measurements, Quat. Geochronol., 3, 174-195, doi:10.1016/j.quageo.2007.12.001.

Bettis, E. A., III, D. R. Muhs, H. M. Roberts, and A. G. Wintle (2003), Last Glacial loess in the conterminous USA, Quat. Sci. Rev., 22, 1907-1946, doi:10.1016/S0277-3791(03)00169-0.

Brantley, S. L., J. Bandstra, J. Moore, and A. F. White (2008), Modelling chemical depletion profiles in regolith, Geoderma, 145, 494-504, doi:10.1016/j.geoderma.2008.02.010.

Brimhall, G. H., and W. E. Dietrich (1987), Constitutive mass balance relations between chemical composition, volume, density, porosity, and strain in metasomatic hydrochemical systems: Results on weathering and pedogenesis, Geochim. Cosmochim. Acta, 51(3), 567-587, doi:10.1016/0016-7037(87)90070-6.

Brimhall, G. H., C. J. Lewis, J. J. Ague, W. E. Dietrich, J. Hampel, T. Teague, and P. Rix (1988), Metal enrichment in bauxites by deposition of chemically mature aeolian dust, Nature, 333, 819-824, doi:10.1038/ $333819 \mathrm{a} 0$.

Brimhall, G. H., O. A. Chadwick, C. J. Lewis, W. Compston, I. S. Williams, K. J. Danti, W. E. Dietrich, M. E. Power, D. Hendricks, and J. Bratt (1992), Deformational mass transport and invasive processes in soil evolution, Science, 255, 695-702, doi:10.1126/science.255.5045. 695.

Bryan, K. (1927), The "Palouse soil" problem, U.S. Geol. Surv. Bull., 790, 21-45.

Burke, B. C., A. M. Heimsath, and A. F. White (2007), Coupling chemical weathering with soil production across soil-mantled landscapes, Earth Surf. Processes Landforms, 32(6), 853-873, doi:10.1002/esp.1443.

Burke, B. C., A. M. Heimsath, J. L. Dixon, J. Chappell, and K. Yoo (2009), Weathering the escarpment: Chemical and physical rates and processes, south-eastern Australia, Earth Surf. Processes Landforms, doi:10.1002/ esp. 1764 .

Busacca, A. J., K. T. Nelstead, E. V. McDonald, and M. D. Purser (1992), Correlation of distal tephra layers in loess in the Channeled Scablands and Palouse of Washington State, Quat. Res., 37, 281-303, doi:10.1016/0033-5894(92)90067-S.

Busacca, A. J., J. E. Beget, H. W. Markewich, D. R. Muhs, N. Lancaster, and M. R. Sweeney (2004), Eolian sediments, in The Quaternary Period in the United States, Dev. Quat. Sci., vol. 1, edited by A. R. Gillespie, S. C. Porter, and B. F. Atwater, pp. 275-309, Elsevier, Amsterdam.

Chadwick, O. A., and J. O. Davis (1990), Soil-forming intervals caused by eolian sediment pulses in the Lahontan basin, northwestern Nevada, Geology, 18, 243-246, doi:10.1130/0091-7613(1990)018<0243: SFICBE $>2.3 . \mathrm{CO} ; 2$.
Chadwick, O. A., L. A. Derry, P. M. Vitousek, B. J. Huebert, and L. O. Hedin (1999), Changing sources of nutrients during four million years of ecosystem development, Nature, 397, 491-497, doi:10.1038/17276.

Chartres, C. J., A. R. Chivas, and P. H. Walker (1988), The effect of aeolian accessions on soil development on granitic rocks in south-eastern Australia. II. Oxygen-isotope, mineralogical and geochemical evidence for aeolian deposition, Aust. J. Soil Res., 26, 17-31, doi:10.1071/ SR9880017.

Cornu, S., Y. Lucas, E. Lebon, J. P. Ambrosi, F. Luizao, J. Rouiller, M. Bonnay, and C. Neal (1999), Evidence of titanium mobility in soil profiles, Manaus, central Amazonia, Geoderma, 91, 281-295, doi:10.1016/S0016-7061(99)00007-5

Dahms, D. E. (1993), Mineralogical evidence for eolian contribution to soils of late Quaternary moraines, Wind River Mountains, Wyoming, USA, Geoderma, 59, 175-196, doi:10.1016/0016-7061(93)90068-V.

Dixon, J. L., A. M. Heimsath, and R. Amundson (2009a), The critical role of climate and saprolite weathering in landscape evolution, Earth Surf. Processes Landforms, doi:10.1002/esp.1836.

Dixon, J. L., A. M. Heimsath, J. Kaste, and R. Amundson (2009b), Climate-driven processes of hillslope weathering, Geology, 37, 975-978, doi:10.1130/G30045A.1.

Eberly, P., L. D. McFadden, and P. M. Watt (1996), Eolian dust as a factor in soil development on the Pajarito Plateau, Los Alamos area, northern New Mexico, in New Mexico Geological Society Guidebook, 47th Field Conference, Jemez Mountains Region, edited by F. Goff et al., pp. 383-389, N. M. Geol. Soc., Socorro.

Ferrier, K. L. (2009), Effects of climate, physical erosion, parent mineralogy, and dust on chemical erosion rates in mountainous terrain, $\mathrm{Ph} . \mathrm{D}$. thesis, Univ. of Calif. Berkeley.

Ferrier, K. L., and J. W. Kirchner (2008), Effects of physical erosion on chemical denudation rates: A numerical modeling study of soil-mantled hillslopes, Earth Planet. Sci. Lett., 272, 591-599, doi:10.1016/j. eps1.2008.05.024.

Fung, I., S. K. Meyn, I. Tegen, S. Doney, J. John, and J. Bishop (2000), Iron supply and demand in the upper ocean, Global Biogeochem. Cycles, 14, 281-295, doi:10.1029/1999GB900059.

Goldstein, H. L., R. L. Reynolds, M. C. Reheis, J. C. Yount, and J. C. Neff (2008), Compositional trends in aeolian dust along a transect across the southwestern United States, J. Geophys. Res., 113, F02S02, doi:10.1029/ 2007JF000751.

Green, E. G., W. E. Dietrich, and J. F. Banfield (2006), Quantification of chemical weathering rates across an actively eroding hillslope, Earth Planet. Sci. Lett., 242, 155-169, doi:10.1016/j.epsl.2005.11.039.

Harden, J. W. (1988), Genetic interpretations of elemental and chemical differences in a soil chronosequence, California, Geoderma, 43, 179-193, doi:10.1016/0016-7061(88)90042-0.

Harrison, S. P., K. E. Kohfeld, C. Roelandt, and T. Claquin (2001), The role of dust in climate changes today, at the Last Glacial Maximum and in the future, Earth Sci. Rev., 54, 43-80, doi:10.1016/S0012-8252 (01)00041-1.

Heimsath, A. M., W. E. Dietrich, K. Nishiizumi, and R. C. Finkel (1997), The soil production function and landscape equilibrium, Nature, 388 , 358-361, doi:10.1038/41056.

Hodson, M. E. (2002), Experimental evidence for mobility of $\mathrm{Zr}$ and other trace elements in soils, Geochim. Cosmochim. Acta, 66, 819-828, doi:10.1016/S0016-7037(01)00803-1.

Jickells, T. D., et al. (2005), Global iron connections between desert dust, ocean biogeochemistry, and climate, Science, 308, 67-71, doi:10.1126/ science. 1105959 .

Kohl, C. P., and K. Nishiizumi (1992), Chemical isolation of quartz for measurement of in situ-produced cosmogenic nuclides, Geochim. Cosmochim. Acta, 56, 3583-3587, doi:10.1016/0016-7037(92)90401-4.

Kurtz, A. C., L. A. Derry, O. A. Chadwick, and M. J. Alfano (2000), Refractory element mobility in volcanic soils, Geology, 28, 683-686, doi:10.1130/0091-7613(2000)28<683:REMIVS $>2.0$. CO;2.

Kurtz, A. C., L. A. Derry, and O. A. Chadwick (2001), Accretion of Asian dust to Hawaiian soils: Isotopic, elemental, and mineral mass balances, Geochim. Cosmochim. Acta, 65, 1971-1983, doi:10.1016/S0016-7037 (01)00575-0.

Litaor, M. I. (1987), The influence of eolian dust on the genesis of alpine soils in the Front Range, Colorado, Soil Sci. Soc. Am. J., 51, 142-147, doi:10.2136/sssaj1987.03615995005100010031x.

Lund, K. (2004), Geology of the Payette National Forest and vicinity, westcentral Idaho, U.S. Geol. Surv. Prof. Pap., 1666.

Marchand, D. E. (1970), Soil contamination in the White Mountains, eastern California, Geol. Soc. Am. Bull., 81, 2497-2506, doi:10.1130/00167606(1970)81[2497:SCITWM]2.0.CO;2.

Merritts, D. J., O. A. Chadwick, D. M. Hendricks, G. H. Brimhall, and C. J. Lewis (1992), The mass balance of soil evolution on late Quaternary 
marine terraces, northern California, Geol. Soc. Am. Bull., 104, 1456-1470, doi:10.1130/0016-7606(1992)104<1456:TMBOSE>2.3.CO;2.

Mudd, S. M., and D. J. Furbish (2006), Using chemical tracers in hillslope soils to estimate the importance of chemical denudation under conditions of downslope sediment transport, J. Geophys. Res., 111, F02021, doi:10.1029/2005JF000343.

Muhs, D. R., C. A. Bush, K. D. Stewart, T. R. Rowland, and R. C. Crittenden (1990), Geochemical evidence of Saharan dust parent material for soils developed on Quaternary limestones of Caribbean and western Atlantic islands, Quat. Res., 33, 157-177, doi:10.1016/0033-5894(90)90016-E.

Pett-Ridge, J. C., L. A. Derry, and A. C. Kurtz (2009), Sr isotopes as a tracer of weathering processes and dust inputs in a tropical granitoid watershed, Luquillo Mountains, Puerto Rico, Geochim. Cosmochim. Acta, 73, 25-43, doi:10.1016/j.gca.2008.09.032.

Porder, S., P. M. Vitousek, O. A. Chadwick, C. P. Chamberlain, and G. E. Hilley (2007), Uplift, erosion, and phosphorus limitation in terrestrial ecosystems, Ecosystems, 10, 158-170, doi:10.1007/s10021-006-9011-x.

Reheis, M. (1990), Influence of climate and eolian dust on the majorelement chemistry and clay mineralogy of soils in the northern Bighorn basin, USA, Catena, 17, 219-248, doi:10.1016/0341-8162(90)90018-9.

Reheis, M. (2006), A 16-year record of eolian dust in Southern Nevada and California, USA: Controls on dust generation and accumulation, J. Arid Environ., 67, 487-520, doi:10.1016/j.jaridenv.2006.03.006.

Reheis, M., and R. Kihl (1995), Dust deposition in southern Nevada and California, 1984-1989: Relations to climate, source area, and source lithology, J. Geophys. Res., 100, 8893-8918, doi:10.1029/94JD03245.

Reheis, M., J. C. Goodmacher, J. W. Harden, L. D. McFadden, T. K. Rockwell, R. R. Shroba, J. M. Sowers, and E. M. Taylor (1995), Quaternary soils and dust deposition in southern Nevada and California, Geol. Soc. Am. Bull., 107, 1003-1022, doi:10.1130/0016-7606(1995) 107<1003:QSADDI>2.3.CO;2.

Reheis, M. C., J. R. Budahn, P. J. Lamothe, and R. L. Reynolds (2009), Compositions of modern dust and surface sediments in the Desert Southwest, United States, J. Geophys. Res., 114, F01028, doi:10.1029/ 2008JF001009.

Rex, R. W., J. K. Syers, M. L. Jackson, and R. N. Clayton (1969), Eolian origin of quartz in soils of the Hawaiian islands and in Pacific pelagic sediments, Science, 163, 277-279, doi:10.1126/science.163.3864.277.

Reynolds, R. L., M. Reheis, J. Yount, and P. Lamothe (2006), Composition of aeolian dust in natural traps on isolated surface of the central Mojave Desert-Insights to mixing, sources, and nutrient inputs, J. Arid Environ., 66, 42-61, doi:10.1016/j.jaridenv.2005.06.031.

Riebe, C. S. (2000), Tectonic and climatic control of physical erosion rates and chemical weathering rates in the Sierra Nevada, California, inferred from cosmogenic nuclides and geochemical mass balance, 212 pp., Ph.D. thesis, Univ. of Calif., Berkeley.

Riebe, C. S., J. W. Kirchner, D. E. Granger, and R. C. Finkel (2001), Strong tectonic and weak climatic control of long-term chemical weathering rates, Geology, 29, 511-514, doi:10.1130/0091-7613(2001) $029<0511$ :STAWCC $>2.0 . \mathrm{CO} ; 2$

Riebe, C. S., J. W. Kirchner, and R. C. Finkel (2003), Long-term rates of chemical weathering and physical erosion from cosmogenic nuclides and geochemical mass balance, Geochim. Cosmochim. Acta, 67, 4411-4427, doi:10.1016/S0016-7037(03)00382-X.
Riebe, C. S., J. W. Kirchner, and R. C. Finkel (2004a), Sharp decrease in long-term chemical weathering rates along an altitudinal transect, Earth Planet. Sci. Lett., 218, 421-434, doi:10.1016/S0012-821X(03)00673-3.

Riebe, C. S., J. W. Kirchner, and R. C. Finkel (2004b), Erosional and climatic effects on long-term chemical weathering rates in granitic landscapes spanning diverse climate regimes, Earth Planet. Sci. Lett., 224 , 547-562, doi:10.1016/j.eps1.2004.05.019.

Stiles, C. A., C. I. Mora, and S. G. Driese (2003), Pedogenic processes and domain boundaries in a Vertisol climosequence: Evidence from titanium and zirconium distribution and morphology, Geoderma, 116, 279-299, doi:10.1016/S0016-7061(03)00105-8.

Sweeney, M. R., D. R. Gaylord, and A. J. Busacca (2007), Evolution of Eureka Flat: A dust-producing engine of the Palouse loess, USA, Quat. Int., 162-163, 76-96, doi:10.1016/j.quaint.2006.10.034.

Taboada, T., A. M. Coritzas, C. Garcia, and E. Garcia-Rodeja (2006), Particle-size fractionation of titanium and zirconium during weathering and pedogenesis of granitic rocks in NW Spain, Geoderma, 131, 218-236, doi:10.1016/j.geoderma.2005.03.025.

White, A. F., A. E. Blum, M. S. Schulz, D. V. Vivit, D. A. Stonestrom M. Larsen, S. F. Murphy, and D. Eberl (1998), Chemical weathering in a tropical watershed, Luquillo Mountains, Puerto Rico: I. Long-term versus short-term weathering fluxes, Geochim. Cosmochim. Acta, 62, 209-226, doi:10.1016/S0016-7037(97)00335-9.

White, A. F., T. D. Bullen, M. S. Schulz, A. E. Blum, T. G. Huntington, and N. E. Peters (2001), Differential rates of feldspar weathering in granitic regoliths, Geochim. Cosmochim. Acta, 65, 847-869, doi:10.1016/ S0016-7037(00)00577-9.

Wilkinson, B. H., and B. J. McElroy (2007), The impact of humans on continental erosion and sedimentation, Geol. Soc. Am. Bull., 119, 140-156, doi:10.1130/B25899.1.

Yoo, K., and S. M. Mudd (2008), Toward process-based modeling of geochemical soil formation across diverse landforms: A new mathematical framework, Geoderma, 146, 248-260, doi:10.1016/j.geoderma.2008.05. 029

Yoo, K., R. Amundson, A. M. Heimsath, W. E. Dietrich, and G. H. Brimhall (2007), Integration of geochemical mass balance with sediment transport to calculate rates of soil chemical weathering and transport on hillslopes, J. Geophys. Res., 112, F02013, doi:10.1029/2005JF000402.

Yoo, K., S. M. Mudd, J. Sanderman, R. Amundson, and A. Blum (2009), Spatial patterns and controls of soil chemical weathering rates along a transient hillslope, Earth Planet. Sci. Lett., 288, 184-193, doi:10.1016/ j.eps1.2009.09.021.

K. L. Ferrier, Department of Earth, Atmospheric, and Planetary Sciences, Massachusetts Institute of Technology, 77 Massachusetts Ave., Cambridge, MA 02139, USA. (kferrier@mit.edu)

R. C. Finkel, Center for Accelerator Mass Spectrometry, Lawrence Livermore National Laboratory, PO Box 808, 7000 East Ave. Livermore, CA 94551, USA.

J. W. Kirchner, Swiss Federal Institute for Forest, Snow, and Landscape Research (WSL), Zuercherstr. 111, Birmensdorf CH-8903, Switzerland. 